\title{
The influence of prey, pastoralism and poaching on the hierarchical use of habitat by an apex predator
}

\author{
Kristoffer T. Everatt ${ }^{1 *}$, Leah Andresen ${ }^{1}$ \& Michael J. Somers ${ }^{1,2}$ \\ ${ }^{1}$ Centre for Wildlife Management, University of Pretoria, Pretoria, South Africa \\ ${ }^{2}$ Centre for Invasion Biology, University of Pretoria, Pretoria, South Africa \\ Received 27 October 2014. To authors for revision 1 December 2014. Accepted 29 January 2015
}

\begin{abstract}
As an apex predator, habitat selection by African lions, Panthera leo, is primarily determined by bottom-up processes; however, increasing anthropogenic pressures may alter these relationships. Using camera traps and track surveys in the Limpopo National Park, Mozambique, we collected detection/non-detection data of lions and their prey and combined these with occurrence data on bushmeat poaching activities and spatial data on agro-pastoralist land use and other landscape features. We used hierarchical modelling within an occupancy framework to determine the relative influences of ecological variables on resource use and non-use by lions at two spatial scales. Habitat use by lions was most strongly influenced by the occurrence of their preferred prey across both spatial scales. However, lions were strongly negatively predicted by bushmeat poaching at the finer spatial scale and generally negatively predicted by agro-pastoralist activities at the coarser scale. Restricting our analysis to the home-range scale would have greatly underestimated the impact of bushmeat poaching on the ecology of lions. The results of our study illustrate the trophic dependency of prey resources to lions and the importance of considering scale when investigating species habitat use. Importantly, our study also demonstrates the limiting influence of bushmeat poaching on the use of habitat by an apex predator.
\end{abstract}

Key words: African lion, occupancy, African carnivore, bushmeat hunting, habitat ecology.

\section{INTRODUCTION}

Considering the biological constraints of obligate carnivory, the use of habitat by apex predators should be primarily predicted by bottom-up processes (Mitchell \& Hebblewhite, 2012). However, competition with humans may alter trophic-based habitat relationships for predators, resulting in reduced habitat availability (Mitchell \& Hebblewhite, 2012; Ripple et al., 2014). For instance, anthropogenic disturbance influences home-range level habitat selection by cougars, Puma concolor, (Dickson \& Beier, 2002), wolves, Canis lupus, (Rich, Mitchell, Gude \& Sime, 2012) and tigers, Panthera tigris (Barber-Meyer et al., 2013).

Competition with humans is recognized as the ultimate cause behind global predator declines (Ripple et al., 2014). However, many apex predator populations exist in human-dominated landscapes (Ripple et al., 2014) or are exposed to human pressures along reserve boundaries (Woodroffe \& Ginsberg, 1998). Understanding how humans

\footnotetext{
To whom correspondence should be addressed. Present address: Centre for African Conservation Ecology, Department of Zoology, Nelson Mandela Metropolitan University, Port Elizabeth, 6031 South Africa. E-mail: kteveratt@gmail.com
}

influence the use of habitat by apex predators is therefore important to improve species conservation and management. For example, knowledge of how humans alter trophic-based habitat relationships for apex predators is an important component of determining habitat suitability and population viability.

Habitat selection can be seen as a hierarchical process (Johnson, 1980), involving behavioural choices that span a continuum of time, space and ecological processes (Mitchell \& Hebblewhite, 2012). Recognizing the scale dependency of variables on species fitness is important for conservation planning. Since species' fitness needs may differ with scale, investigations limited to a singular scale may fail to recognize the importance of key habitat components (Nams, Mowat \& Panian, 2006). For instance, Ciarniello, Boyce, Seip \& Heard (2007) demonstrated how delineating protected areas for grizzly bears, Ursus arctos, based on habitat selection at the third-order would have excluded important landscape features whose importance only became evident at the home-range scale. 
The contemporary distribution of the African lion, Panthera leo, is largely associated with the remaining extent of intact savanna (Riggio et al., 2012). At the home-range scale, lions may select for areas with relatively higher densities of large ungulates (Van Orsdol, Hanby \& Bygott, 1985), and may select against areas with increased threat of human persecution (Ogutu, Bhola \& Reid, 2005, but see; Woodroffe \& Frank, 2005). Lion foraging success requires a combination of prey availability and suitable cover from which to attack (Hopcraft, Sinclair \& Packer, 2005; Mosser, Fryxell, Eberly \& Packer, 2009). At the fourth-order scale of habitat use, lions may select areas with preferred hunting features over areas with higher prey densities (Mosser et al., 2009; Davidson et al., 2013). Stalking and ambush cover are less limiting to lions in forested savannas (Funston, Mills, Biggs \& Richardson, 1998; Hopcraft et al., 2005), than to lions on open plains (Hopcraft et al., 2005; Mosser et al., 2009).

The goal of this study was to determine the relative influence of bottom-up resource and topdown anthropogenic factors on the hierarchical use of habitat by lions in a system impacted by pastoralism and poaching. We considered the Limpopo National Park (LNP) in southwestern Mozambique as an ideal case study location because both lions and humans are resident in the park, and humans freely extract resources, including 'bushmeat', graze livestock, and are known to persecute lions (Everatt, Andresen \& Somers, 2014). We measured habitat use by lions within an occupancy modelling approach that explicitly accounts for survey and site level species detectability (MacKenzie et al., 2002; Mitchell \& Hebblewhite, 2012). Discreet occupancy models were also developed for the variables describing resources and threats encountered by lions in LNP. We predicted that habitat use by lions in LNP would reflect their ecological niche as an apex predator and be primarily predicted by bottom-up processes, but that the threats posed to lions by top-down anthropogenic pressures would strongly determine the use of habitat. In addition, we predicted that the relative importance of variables describing lion habitat would vary with scale.

\section{METHODS}

\section{Study area}

The study was conducted in a $2400 \mathrm{~km}^{2}$ area of woodland savanna plains in Mozambique's Limpopo National Park (LNP) (UTM X 384502 UTM Y 7432635) (Fig. 1). LNP forms a component of the Greater Limpopo Trans-frontier Park (GLTFP) with Kruger National Park (KNP), South Africa and Gonarezhou National Park, Zimbabwe. Together these parks form the core of the Greater

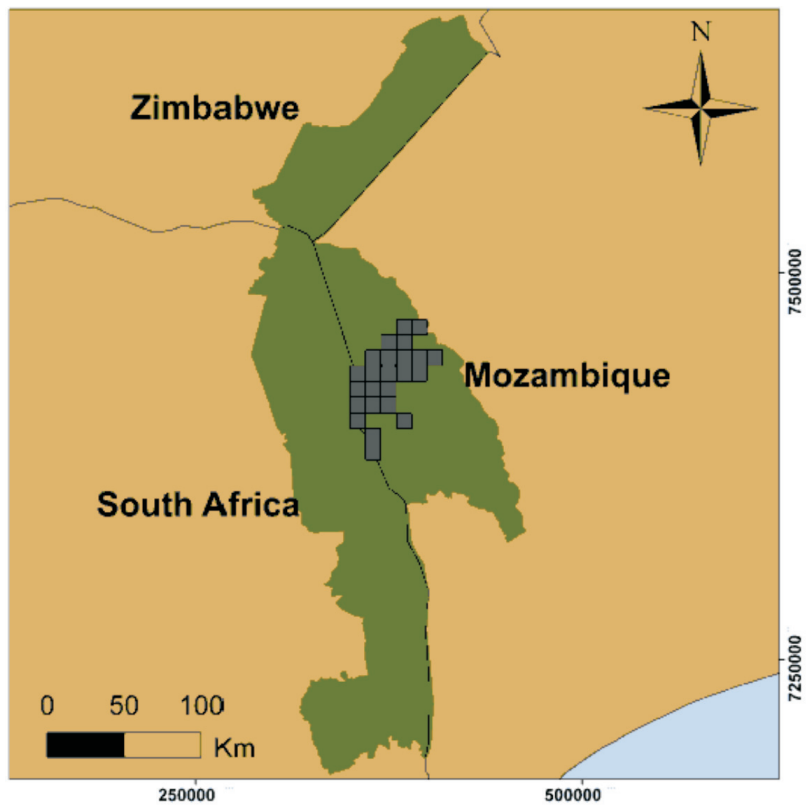

Fig. 1. Location of study area (squares) within Limpopo National Park, which forms the Mozambican component of the Greater Limpopo Trans-frontier Park (in green). 
Limpopo Lion Conservation Unit (IUCN, 2006). The study area is bordered to the west by KNP and to the east by a near continuous band of agropastoralist settlements along the banks of the Limpopo River. There are additional smaller agro-pastoralist settlements situated within the study area. The human population is estimated at 6500 (in 2003) in LNP and 20000 living in the eastern boundary villages (Huggins, Barendse, Fischer \& Sitoi, 2003), together grazing over 20000 cattle, Bos primigenius (Stephensen, 2010).

Wildlife in this region of Mozambique were largely decimated during 28 years of war (1964-1992) (Hatton, Couto \& Oglethorpe, 2001). However, removal of portions of the South AfricaMozambique border fence as part of the creation of the GLTFP in 2000 has provided opportunities for re-colonization of wildlife into LNP (Hanks, 2000), and currently $23 \mathrm{spp}$. of ungulates occur in the Park (Everatt, 2014). At the time of this study, the lion population in LNP was estimated at 66 individuals or a density of 0.99 lions $/ 100 \mathrm{~km}^{2}$ (Everatt et al., 2014).

\section{Survey design}

It is possible to examine habitat use at multiple spatial scales using sampling windows of differing, biologically relevant sizes (Baldwin \& Bender, 2008; Sunarto et al., 2012). In this study, we examined habitat use by lions at two spatial scales equivalent to Johnson's (1980) second- and thirdorder of habitat selection. We defined secondorder sampling sites as $100 \mathrm{~km}^{2}$ grid cells, based on average home-range sizes of lions in the adjoining and contiguous KNP (Funston, Mills, Richardson \& Van Jaarsveld, 2003.) (Fig. 1). Included within these grid cells we defined third-order sites as approximately $1 \mathrm{~km}^{2}$, reasoning this size was biologically meaningful to the scale at which lions make short-term habitat-use decisions.

To quantify habitat use by lions we employed an occupancy modelling approach where the estimator $(\Psi)$ was defined as the probability of site use (MacKenzie et al., 2006). We made the following assumptions; 1) species were not falsely identified, 2) detections were independent, 3) heterogeneities in occupancy or detection probabilities were modelled using covariates. It is important to note that the closure assumption could be relaxed because our estimator was probability of site use rather than proportion of area occupied (MacKenzie et al., 2006 p. 105).

\section{Data collection}

We collected the data from temporally replicated detection/non-detection camera trap and spoor surveys conducted from 9 September 2011 to 26 November 2012. We deployed digital motion cameras (15 Reconyx HC500 (Wisconsin, U.S.A.) (trigger time of $0.97 \mathrm{~s}$, detection zone approximately $24 \mathrm{~m}$ ), 7 Spy Point Tiny-W2 (Québec, Canada) (trigger time of $0.91 \mathrm{~s}$, detection zone approximately $17 \mathrm{~m}$ ), 10 Bushnell Trophy Cam (Beijing, China) (trigger time of $0.66 \mathrm{~s}$, detection zone approximately $18 \mathrm{~m}$ ) (http://www.trailcampro. com/trailcamerareviews.aspx) on dirt tracks, game trails and along river edges. In addition, we conducted track surveys on foot due to the lack of road networks in the study area. These surveys followed an obvious path of travel, (i.e. track, game trail or river edge) where substrate was adequate for tracking.

Sampling occasions at the home-range scale were represented by 189 temporally replicated $3 \mathrm{~km}$ transect samples (replicates separated by $>14$ days) and 326, 14-day camera-trap samples for a combined mean of 21.6 samples per grid cell. Of the 24 grid cells, 23 were sampled with cameratraps (mean $=14$ samples/grid cell, range $=3-30$ samples/grid cell) and 23 were sampled with track surveys $($ mean $=8$ samples $/$ grid cell, range $=2-16$ samples/grid cell). We note here that unequal sampling across sites is accounted for within an occupancy model (MacKenzie et al., 2002). In an effort to meet the assumption of independence between sampling occasions at the home-range scale, we pooled detections (within grid cells) when a camera-trap had sampled anytime 14 days prior to a track transect. Sample occasions at the short-term use scale were represented by 998 temporally replicated $1 \mathrm{~km}$ transects (232 sites; 638 samples) (replicates separated by 14 days) and 14 day camera-trap samples (82 sites; 360 samples) for a combined mean of 3.6 samples per site. Of the total 260 sites surveyed, 184 sites were sampled only by transects, 48 were sampled by transects and camera-traps, and 28 sampled only by camera-traps. The detection or non-detection of lions was recorded for each (14 day) camera trapping sample and each $(1 \mathrm{~km})$ track transect sample.

\section{Identification of covariates}

To explain habitat use by lions in a humandisturbed landscape, we considered five fitnessrelated covariates. These included: encounter 
Table 1. Covariates expected to influence habitat use by lions.

\begin{tabular}{llllll}
\hline Covariate & Key & Fitness value to lion & Description & $\begin{array}{l}\text { Sampling range: } \\
\text { short-term habitat } \\
\text { use }\end{array}$ & $\begin{array}{l}\text { Sampling range: } \\
\text { home-range } \\
\text { habitat use }\end{array}$ \\
\hline Preferred prey & PP & Availability of preferred prey & Probability of buffalo site use & $\begin{array}{l}0.1-0.5 \\
\text { mean }=0.4\end{array}$ & $\begin{array}{l}0.1-0.6 \\
\text { mean }=0.4\end{array}$ \\
Alternate prey & AP & Availability of alternate prey & $\begin{array}{l}\sum \text { Probability of warthog } \\
\text { and impala site use }\end{array}$ & $\begin{array}{l}0.1-1.7 \\
\text { mean }=1.0\end{array}$ & $\begin{array}{l}0.2-1.5 \\
\text { mean }=0.9\end{array}$ \\
Bushmeat poaching & B & Targeted or accidental snaring & $\begin{array}{l}\text { Probability of bushmeat } \\
\text { poaching site use }\end{array}$ & $\begin{array}{l}0.0-1.0 \\
\text { mean }=0.6\end{array}$ & $\begin{array}{l}0.1-1.0 \\
\text { mean }=0.6\end{array}$ \\
Village & V & $\begin{array}{l}\text { Persecution in defense of } \\
\text { livestock }\end{array}$ & $\begin{array}{l}\text { Proximity to agro-pastoralist } \\
\text { settlements }(\mathrm{km})\end{array}$ & $\begin{array}{l}0.1-24.5 \\
\text { mean }=10.9\end{array}$ & $\begin{array}{l}2.0-20.4 \\
\text { mean }=11.2\end{array}$ \\
& Riparian & Randscape feature facilitating & $\begin{array}{l}\text { Amount of riparian area in site } \\
(\# 30 \times 30 \mathrm{~m} \text { pixels })\end{array}$ & $\begin{array}{l}0.0-2.7 \\
\text { mean }=0.1\end{array}$ & $\begin{array}{l}0.0-928.1 \\
\text { mean }=315.3\end{array}$ \\
\hline
\end{tabular}

probability of lion's preferred prey, encounter probability of alternate prey, landscape features that facilitate prey capture (i.e. riparian areas), encounter probability of bushmeat poaching and agro-pastoralist use (Table 1).

Lions exhibit a strong preference for larger bodied prey including African buffalo, Syncerus caffer, (Hayward \& Kerley, 2005). To quantify the influence of preferred prey availability on habitat use by lions, we used a probability of occurrence model for buffalo that was developed by Everatt et al., (2014) for the same survey area and time. Other species that lions are known to preferentially select for, including; giraffe, Giraffa camelopardalis, plains zebra, Equus quagga, and blue wildebeest, Connochaetes taurinus, (Hayward \& Kerley, 2005), were excluded from the analysis because they have a limited distribution of occurrence in the study area (Stephensen, 2010). To quantify the influence of alternate prey availability for lions, we combined probability of site use for warthog, Phacochoerus africanus, (Supplementary information, http://dx.doi.org/10.6084/m9.figshare. 1295207) and impala, Aepyceros melampus, (Andresen, Everatt \& Somers, 2014) from models developed for the same survey and time. We assumed that the probability of prey occurrence (i.e. site use) is biologically representative of an encounter probability for lions. To quantify the influence of bushmeat poaching on habitat use by lions, we used a bushmeat poaching occupancy model developed by Everatt et al., (2014) for the same study area and time. Agro-pastoralist use was measured as the mean Euclidean distance to a settlement edge per $30 \mathrm{~m} \times 30 \mathrm{~m}$ pixel in a grid cell (home-range analysis) or in a buffer
(50 m diameter) placed around each camera station or track transect (short-term site use analysis) from a landscape raster (Peace Parks Foundation, Stellenbosch). We considered riparian areas as a proxy for landscape features that facilitate prey capture (Hopcraft et al., 2005), measured as the number of $30 \mathrm{~m} \times 30 \mathrm{~m}$ pixels (per grid cell or buffer) overlapping either river (including drainage lines) or water (including pans) raster layers (Peace Parks Foundation, Stellenbosch). Analyses were made in the Spatial Analysis tool in ArcGIS 9.3.1. (ESRI, Redlands, California, U.S.A.).

\section{Analytical methods}

We constructed a detection/non-detection matrix for each site and spatial scale, recording a ' 1 ' or ' 0 ' where lions were detected or not detected, respectively. Following this, we constructed two surveyspecific matrices for each analysis to account for differences in detectability between the two sampling methods used. In the first matrix a ' 1 ' was recorded where only the method 'track' was employed and a ' 0 ' where only cameras were employed. In the second matrix, a '1' was recorded where each method was used and data were pooled, and a ' 0 ' where only one method was used. The overlap of the two matrices therefore accounted for three sampling possibilities at each site; tracks only, cameras only and pooled samples. Additionally, we constructed season specific (wet versus dry) matrices, recording a ' 1 ' for surveys conducted during the wet season and a ' 0 ' for surveys conducted during the dry season. To account for variation in lion detection probability $(p)$ the covariates 'track' and 'pooled' (hereafter referred to as method ' $M$ ') and 'season' were 
Table 2. Results from discreet occupancy models describing the probability of detection $(\overline{\hat{p}})$ and probability of site use $\bar{\Psi})$ by bushmeat poachers, buffalo, impala and warthog from camera trapping data in Limpopo National Park, September 2011 to November 2012.

\begin{tabular}{lcccc}
\hline & $\overline{\hat{p}}$ & S.E. & $\overline{\hat{\Psi}}$ & S.E. \\
\hline Bushmeat poachers $^{*}$ & 0.165 & 0.027 & 0.799 & 0.050 \\
Buffalo $^{*}$ & 0.368 & 0.041 & 0.416 & 0.084 \\
Impala $^{\ddagger}$ & 0.285 & 0.038 & 0.482 & 0.090 \\
Warthog $^{\dagger}$ & 0.336 & 0.035 & 0.513 & 0.049 \\
\hline
\end{tabular}

From * Everatt et al., (2014), ${ }^{\ddagger}$ Andresen et al., (2014), ${ }^{\dagger}$ Supplementary information http://dx.doi.org/10.6084/m9.figshare.1295207

included in all models describing lion site use $(\Psi)$.

We estimated site occupancy $(\Psi)$ and detection probability $(p)$ using maximum likelihood functions (MacKenzie et al., 2006) and the single season option in the program PRESENCE Version 5.5 (Hines, 2006). Continuous site covariates were standardized on a $z$-scale and all covariates were tested for collinearity using a cut-off of $r=0.5$. Covariates found to be correlated were not included in the same models. All possible (non-correlated) combinations of occupancy covariates (Supplementary information, http://dx.doi.org/10.6084/ m9.figshare.1295207) were considered for each analysis (home-range scale $=11$ models, shortterm site use scale $=16$ models). We ranked models based on Akaike Information Criterion (AIC), using AICc adjusted for small sample size, with the sample size set as the number of sampling sites (Burnham \& Anderson, 2002). Models with a $\triangle \mathrm{AICc}<2$ were considered to have strong support. We considered a candidate set of all models $\triangle \mathrm{AICc}<7$ whose combined weights $\geq 0.95$ (i.e. $95 \%$ confidence set). AICc weights were used to determine the weight of evidence for each model, and were summed for each covariate in the 95\% confidence set (Burnham \& Anderson, 2002). Variables with high summed model weights were considered more important in explaining heterogeneity in occupancy. The direction of influence of individual covariates was determined by the sign of the $\beta$-coefficients (MacKenzie et al., 2006). Covariates were considered to have strong or robust impact if $\beta \pm 1.96 \times \mathrm{S}$. E. from the top ranking model were not overlapping zero. We used a weighted model averaging technique to calculate overall parameter estimates (Burnham \& Anderson, 2002). Finally, we performed a goodness of fit test using 10000 bootstrap samples and a Pearson's chi-square statistic on the most saturated model (MacKenzie \& Bailey, 2004).

\section{RESULTS}

We recorded a total survey effort of 5335 camera trap nights and $638 \mathrm{~km}$ of track surveys. After pooling sampling occasions, the final data set consisted of 251 sampling occasions at the homerange scale and 957 sampling occasions at the short-term site-use scale. Lions were detected on 35 (14 day) camera samples (from 664 lion photos) and $55(1 \mathrm{~km})$ track samples. We identified 19 individual lions from camera-trap images, with identification based on sex, age and distinguishing scars (Whitman \& Packer, 2007). This number is therefore the minimum sample size of individuals considered in this habitat analysis. The probability of site use by lion's prey and by bushmeat poachers is summarized in Table 2 .

\section{Habitat use at the home-range scale}

The model averaged probability of detecting lions where they occurred at the home-range scale was $\overline{\hat{p}}=0.304$ (S.E. $=0.095)$. The covariate preferred prey was strongly supported and was the principal contributing factor to habitat use by lions at this spatial scale; the only model that emerged with a $\triangle \mathrm{AICc}<2$ was the univariate model $\Psi(\mathrm{P}) \mathrm{p}(\mathrm{M}+\mathrm{S})$ (Tables 3 \& 4). Lions showed a strong use of sites with a greater probability of occurrence of their preferred prey (Tables $3 \& 4$ ). In addition, lions generally occurred at sites with a greater proportion of riparian areas that were further from villages with a greater probability of occurrence of alternate prey and lower probability of occurrence of bushmeat poaching (Table 4). There was no evidence lack of fit $(p=0.22)$ or over-dispersion $(\hat{c})=1.20$ )

\section{Habitat use at the short-term use scale}

The model averaged probability of detecting lions where they occurred at the short-term use scale was $\bar{p}=0.230$ (S.E. $=0.038$ ). The greatest contributing factors to habitat use by lions at this 
Table 3. Summary of model selection procedure for factors influencing site use $(\Psi)$ by lions at the home-range scale and at the short-term use scale. Covariates considered include; occurrence probability of preferred prey $(P)$, occurrence probability of alternate prey $(A P)$, occurrence probability of bushmeat poaching $(B)$, distance from villages (V) and proportion of riparian area (W).

\begin{tabular}{|c|c|c|c|c|}
\hline Model & $\triangle \mathrm{AICc}$ & $w$ & $K$ & $-2 \mid$ \\
\hline \multicolumn{5}{|l|}{ Home-range use } \\
\hline$\Psi(P) p(M+S)$ & 0.00 & 0.372 & 6 & 151.44 \\
\hline$\Psi(\mathrm{V}) \mathrm{p}(\mathrm{M}+\mathrm{S})$ & 2.47 & 0.108 & 6 & 153.91 \\
\hline$\Psi(\mathrm{P}+\mathrm{R}) \mathrm{p}(\mathrm{M}+\mathrm{S})$ & 2.89 & 0.088 & 7 & 150.27 \\
\hline$\Psi(\mathrm{R}) \mathrm{p}(\mathrm{M}+\mathrm{S})$ & 3.45 & 0.066 & 6 & 154.89 \\
\hline$\Psi(.) \mathrm{p}(\mathrm{M}+\mathrm{S})$ & 3.52 & 0.064 & 5 & 158.57 \\
\hline$\Psi(A P) p(M+S)$ & 3.54 & 0.063 & 6 & 154.98 \\
\hline$\Psi(\mathrm{P}+\mathrm{B}) \mathrm{p}(\mathrm{M}+\mathrm{S})$ & 3.58 & 0.062 & 7 & 150.96 \\
\hline$\Psi(\mathrm{AP}+\mathrm{R}) \mathrm{p}(\mathrm{M}+\mathrm{S})$ & 4.18 & 0.046 & 7 & 151.56 \\
\hline$\Psi(\mathrm{R}+\mathrm{V}) \mathrm{p}(\mathrm{M}+\mathrm{S})$ & 4.21 & 0.045 & 7 & 151.59 \\
\hline$\Psi(B+R) p(M+S)$ & 5.50 & 0.024 & 7 & 152.88 \\
\hline$\Psi(\mathrm{P}+\mathrm{B}+\mathrm{R}) \mathrm{p}(\mathrm{M}+\mathrm{S})$ & 5.72 & 0.021 & 8 & 148.50 \\
\hline \multicolumn{5}{|l|}{ Short-term use } \\
\hline$\Psi(\mathrm{P}+\mathrm{B}) \mathrm{p}(\mathrm{M})$ & 0.00 & 0.574 & 6 & 539.79 \\
\hline$\Psi(\mathrm{P}+\mathrm{B}+\mathrm{R}) \mathrm{p}(\mathrm{M})$ & 1.08 & 0.334 & 7 & 538.76 \\
\hline$\Psi(\mathrm{P}) \mathrm{p}(\mathrm{M})$ & 4.27 & 0.068 & 5 & 546.15 \\
\hline$\Psi(\mathrm{P}+\mathrm{R}) \mathrm{p}(\mathrm{M})$ & 6.33 & 0.024 & 6 & 546.12 \\
\hline$\Psi(.) \mathrm{p}(\mathrm{M})$ & 29.18 & 0.000 & 4 & 573.14 \\
\hline
\end{tabular}

Detectability $(\mathrm{p})$ varies with method $(\mathrm{M})$ and season $(\mathrm{S}) . \Psi($.$) assumes site use is constant, \Delta \mathrm{AICc}$ is the difference in AICc values between each model with the low AICc model, $w$ is the AICc model weight, $K$ is the number of parameters in the model, and -2l is twice the negative log-likelihood value.

scale were the probability of occurrence of their preferred prey and the probability of occurrence of bushmeat poaching (Tables $3 \& 4$ ), where lions showed a strong use of sites with a greater probability of occurrence of their preferred prey and a strong negative use of sites with a greater probability of occurrence of bushmeat poaching (Tables

Table 4. $\beta$-coefficient estimates for covariates influencing site use $(\Psi)$ by lions in order of their summed model weights $(\Sigma w)$ at the home range use scale and at the short-term use scale.

\begin{tabular}{lcrl}
\hline Occupancy covariate & $\Sigma$ model w (\%) & $\beta$ & S.E. \\
\hline Home-range use & & & \\
Preferred prey & 57.6 & $9.82^{*}$ & 4.73 \\
Riparian & 20.4 & 0.57 & 0.62 \\
Villages & 16.8 & -1.12 & 0.64 \\
Alternate prey & 10.7 & 2.51 & 1.57 \\
Bushmeat poaching & 7.0 & -1.13 & 1.69 \\
Short-term use & & & \\
Preferred prey & 99.9 & $8.62^{*}$ & 2.49 \\
Bushmeat poaching & 90.8 & $-1.50^{*}$ & 0.63 \\
Riparian & 35.9 & 0.56 & 0.46 \\
\hline
\end{tabular}

${ }^{*}$ Indicates covariate has robust impact $\beta \pm 1.96 \times$ S.E. not overlapping 0).
3 \& 4). In addition, lions generally occurred at sites closer to riparian areas (Table 4). There was no evidence of a lack of fit $(P=0.41)$ or overdispersion $(\hat{c}=0.44)$.

\section{DISCUSSION}

In this study we considered use of habitat by an apex predator that co-occurs with human activities. Our results demonstrate that habitat use by lions is influenced by bottom-up resources and by topdown anthropogenic pressures (Fig. 2). In addition, we found that the limiting influence of bushmeat poaching was scale dependent, which has important conservation implications.

\section{Habitat use by an apex predator was most predicted by bottom-up processes}

Habitat use by lions in LNP was most strongly predicted by the occurrence of buffalo. The importance of this variable was indicated by the weight of evidence for models containing the buffalo covariate and by the strong positive influence of this covariate at the coarser home-range spatial scale. That the buffalo covariate was strongly determining across both spatial scales emphasizes the importance of this component of lion 


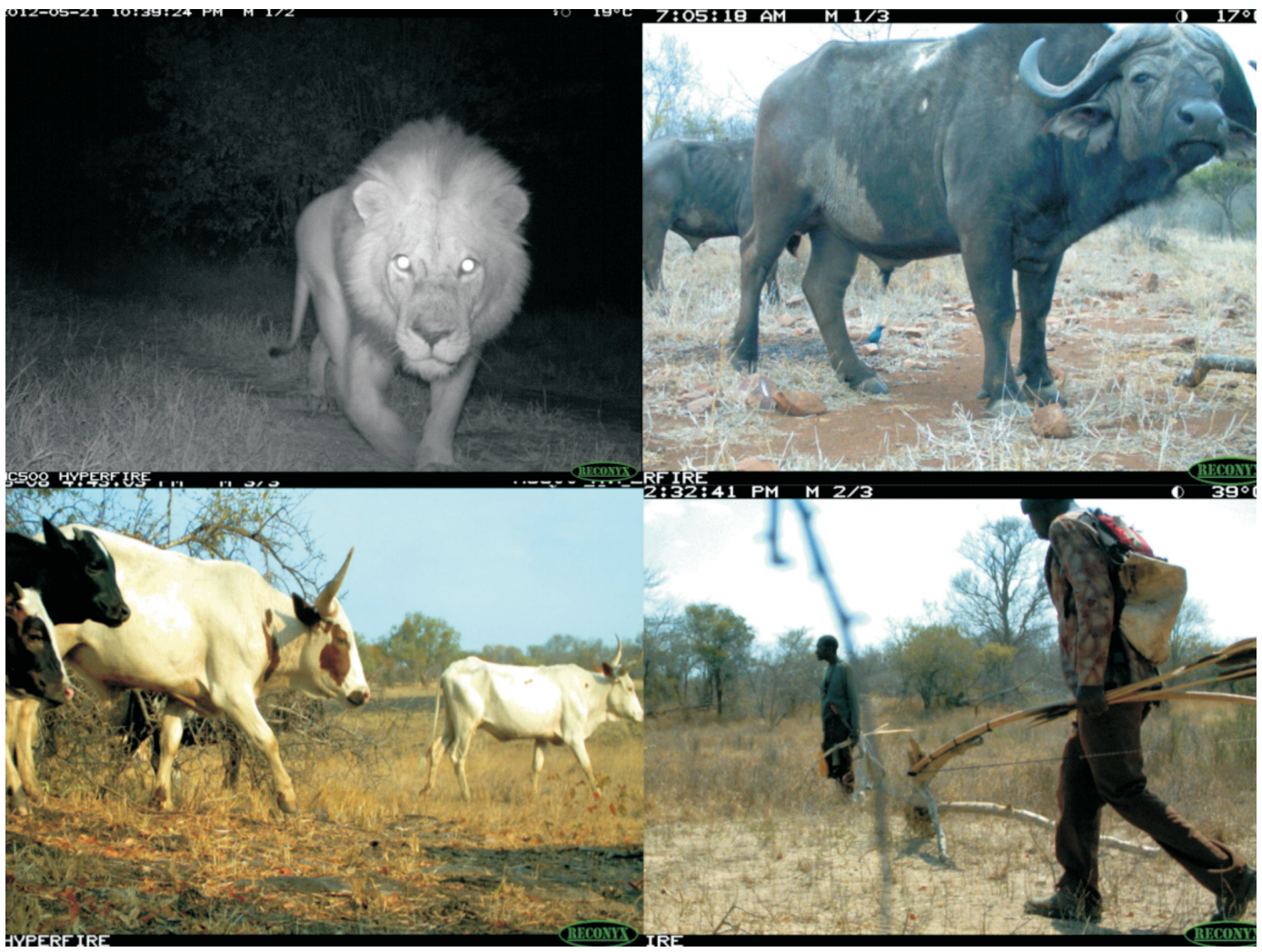

Fig. 2. Habitat use by lions in the Limpopo National Park is influenced by bottom-up resources and by top-down anthropogenic pressures including pastoralism and bushmeat poaching.

habitat use (Rettie \& Messier, 2000). These results suggest that lions in LNP are making behavioural choices to select habitat at the homerange scale that includes the limited distribution of buffalo herds in the park and then further selecting areas at a finer spatial scale that would increase their probability of encountering individual animals.

That habitat use by lions was strongly determined by the occurrence of prey resources agrees with trophic-based species-habitat relationships (Krebs, 2009; Mitchell \& Hebblewhite, 2012). For instance, food resources were the primary predictor of second-order habitat selection by grizzly bears in the Canadian Arctic (McLoughlin et al., 2002) and tigers in the Russian Far East (Miquelle et al., 1999). Following this, predation risk by wolves was the primary predictor of second-order habitat selection by caribou, Rangifer tarundus, in northern Canada (Rettie \& Messier, 2000) and predation risk by lions was the primary predictor of second-order habitat selection by zebra, giraffe and wildebeest on a reserve in South Africa (Thaker et al., 2011).
Habitat use by an apex predator is influenced by top-down anthropogenic disturbance

Habitat use by lions in LNP was strongly negatively predicted by bushmeat poaching at the short-term use spatial scale. Bushmeat poaching may limit predator habitat by depletion of prey resources and by direct, targeted or non-targeted, persecution (Becker et al., 2013; Lindsey et al., 2013; Everatt et al., 2014). During this study we found evidence of three lions that were killed by bushmeat poachers, thus reducing lion occurrence at these sites. In addition, by modelling prey occurrence, we were able to exclude the influence of prey depletion by bushmeat poaching, thus limiting our poaching covariate to describe the direct persecution of lions in LNP. However, applying this approach could mean that the total influence of bushmeat poaching (prey depletion and persecution) is underrepresented in our hierarchical ranking of explanatory covariates.

Finally, our results demonstrate the scale dependency of lion-habitat associations. While the importance of prey resources to the use of habitat 
by lions in LNP spanned the domain of both spatial scales examined, the limiting influences of the anthropogenic covariates varied with spatial scale. Our results show that considering habitat selection by lions only at the home-range scale would have greatly underestimated the direct impacts of bushmeat poaching on lion ecology. This is concerning because failing to recognize the impact of bushmeat poaching could lead to erroneous conclusions of lion habitat suitability and population viability.

Mechanisms responsible for the species-habitat relationships we present may include a behavioural or numerical response. Avoidance of pastoralism and bushmeat poaching by lions could indicate that lions possess a behavioural mechanism to reduce competition with humans (Schuette, Creel \& Christianson, 2013). Alternatively, if reduced site use indicates a numerical response by lions then this could suggest that the human-impacted lands of LNP are acting as sink or as attractive-sink (Battin, 2004) habitat to the adjoining (source) habitat in KNP. In the context of acute continental range declines and the isolation of lion populations, sink habitats, although low in quality, may nonetheless be important to lion conservation by increasing lion range and maintaining genetic connectivity (Dolrenry, Stenglein, Hazzah, Lutz \& Frank, 2014; Stoner et al., 2013). Under this scenario, LNP may offer range expansion and connectivity and thus play an important role in the viability of lions in the Greater Limpopo Lion Conservation Unit. Conversely, if lions are mistakenly selecting for human use areas (i.e. for cattle as prey and/or wildlife areas used by poachers) and suffering high levels of mortality, LNP could be acting as an attractive sink, which could reduce the viability of the greater lion population (Battin, 2004). Distinguishing between sink and attractive-sink habitats is therefore important for improving lion conservation prospects in the system.

\section{ACKNOWLEDGEMENTS}

We thank the Parque Nacional do Limpopo for supporting this research and the Director of $\mathrm{Na}$ tional Conservation Areas Mozambique for granting us the research permits (005-2011/003-2012) to conduct this study. We thank Eden Everatt for help and enthusiasm in the field. K.T.E. and L.A. were supported by the May and Stanley Smith Trust, The Wipplinger KL Bursary Found, Wilderness Wildlife Trust and Canada National Student Grants. The funders had no role in study design, data collection and analysis, decision to publish, or preparation of the manuscript. We thank Matt Hayward and an anonymous reviewer whose input greatly improved the manuscript.

\section{REFERENCES}

Andreasen, A.M., Stewart, K.M., Longland, W.S., Beckmann, J.P. \& Forister, M.L. (2012). Identification of source-sink dynamics in mountain lions of the Great Basin. Molecular Ecology, 21, 5689-5701.

Andresen, L., Everatt, K.T. \& Somers, M.J. (2014). Use of site occupancy models for targeted monitoring of the cheetah. Journal of Zoology, 292, 212-220.

Baldwin, R.A. \& Bender, L.C. (2008). Distribution, occupancy, and habitat correlates of American Martens (Martes americana) in Rocky Mountain National Park, Colorado. Journal of Mammalogy, 89, 419427.

Barber-Meyer, S.M., Jnawali, S.R., Karki, J.B., Khanal, P., Lohani, S., Long, B., MacKenzie, D.I., Pandav, B., Pradhan, N.M.B., Shrestha, B.R., Subedi, N., Thapa, G., Thapa, K. \& Wikramanayake, E. (2013). Influence of prey depletion and human disturbance on tiger occupancy in Nepal. Journal of Zoology, 289, 10-18.

Battin, J. (2004). When good animals love bad habitats: Ecological traps and the conservation of animal populations. Conservation Biology, 18, 1482-1491.

Becker, M., McRobb, R., Watson, F., Droge, E., Kanyembo, B., Murdoch, J. \& Kakumbi, C. (2013). Evaluating wire-snare poaching trends and the impacts of by-catch on elephants and large carnivores. Biological Conservation, 158, 26-36.

Burnham, K.P. \& Anderson, D.R. (2002). Model selection and multimodel inference: a practical informationtheoretic approach, 2nd edn. Springer Science, New York.

Ciarniello, L.M., Boyce, M.S., Seip, D.R. \& Heard D.C. (2007). Grizzly bear habitat selection is scale dependent. Ecological Applications, 17, 1424-1440.

Davidson, Z., Valeix, M., Van Kesteren, F., Loveridge, A.J., Hunt, J.E., Murindagamo, F. \& MacDonald, D.W. (2013). Seasonal diet and prey preference of the African lion in a waterhole-driven semi-arid savanna. PLOS ONE 8, e55182. DOI: 10.1371/journal.pone. 0055182.

Dickson, B.G. \& Beier, P. (2002). Home-range and habitat selection by adult cougars in southern California. Journal of Wildlife Management, 66, 1235-1245.

Dolrenry, S., Stenglein, J., Hazzah, L., Lutz \& Frank, L. (2014). A metapopulation approach to African lion (Panthera leo) conservation. PLOS ONE 9, e88081.

Everatt, K.T. (2014). Influence of bushmeat poaching and pastoralism on African lion, Panthera leo (Linnaeus, 1758), ecology in rural Mozambique. (Unpublished M.Sc. thesis). Pretoria: University of Pretoria.

Everatt, K.T., Andresen, L. \& Somers, M.J. (2014). Trophic scaling and occupancy analysis reveals a lion population held below carrying capacity by top-down anthropogenic pressure in the Limpopo National Park, Mozambique. PLOS ONE, 9, e99389. DOI: 10.1371/journal.pone.0099389.

Funston, P.J., Mills, M.G.L., Biggs, H.C. \& Richardson, P.R.K. (1998). Hunting by male lions: ecological influ- 
ences and socioecological implications. Animal Behavior, 56, 1333-1345.

Funston, P.J., Mills, M.G.L., Richardson, P.R.K. \& Van Jaarsveld, A.S. (2003). Reduced dispersal and opportunistic territory acquisition in male lions (Panthera leo). Journal of Zoology, 259, 131-142.

Gertenbach, W.P.D. (1980). Rainfall patterns in the Kruger National Park. Koedoe, 23, 35-43.

Hatton, J., Couto, M. \& Oglethorpe, J. (2001). Biodiversity and war: a case study of Mozambique. Washington, D.C.: Biodiversity Support Program.

Hanks, J. (2003). Transfrontier Conservation Areas (TFCAs) in southern Africa: their role in conserving biodiversity, socioeconomic development and promoting a culture of peace. Journal of Sustainable Forestry, 17, 1-20.

Hayward, M.H. \& Kerley, G.I.H. (2005). Prey preferences of the lion (Panthera leo). Journal of Zoology, 267, 309-322.

Hebblewhite, M., Miquelle, D.G., Murzin, A.A., Aramilev, V.V. \& Pikunov, D.G. (2011). Predicting potential habitat and population size for reintroduction of the Far Eastern leopards in the Russian Far East. Biological Conservation, 144, 2403-2413.

Hines, J.E. (2006). PRESENCE-Software to estimate patch occupancy and related parameters. USGSPWRC, http://www.mbr.pwrc.usgs.gov/software/ presence.html

Hopcraft, G.J.C., Sinclair, A.R.E \& Packer, C. (2005). Planning for success: Serengeti lions seek prey accessibility rather than abundance. Journal of Animal Ecology, 74, 559-566.

Huggins, G., Barendse., E., Fischer, A \& Sitoi, J. (2003). Limpopo National Park: resettlement policy framework. Unpublished Report.

Johnson, D.H. (1980). The comparison of usage and availability measurements for evaluating resource preference. Ecology, 61, 65-71.

Krebs, C.J. (2009). Ecology: the experimental analysis of distribution and abundance. San Francisco: Benjamin Cummings.

Lindsey, P.A., Balme, G., Becker, M., Begg, C., Bento, C., Bocchino, C., Dickman, A., Diggle, R.W., Eves, H., Henschel, P., Lewis, D., Marnewick, K., Mattheus, J., McNutt, W., McRobb, R., Midlane, N., Milanz, J., Morley, R., Murphree, M., Opyene, V., Phadima, J., Purchase, G., Rentsch, D., Roche, C., Shaw, J., Van der Westhuizen, H., Van Vliet, N. \& ZisadzaGandiwa, P. (2013). The bushmeat trade in African savannas: Impacts, drivers, and possible solutions. Biological Conservation, 160, 80-96.

MacKenzie, D.I. \& Bailey, L.L. (2004). Assessing the fit of site-occupancy models. Journal of Agricultural, Biological and Environmental Statistics, 9, 300-318.

MacKenzie, D.I., Nichols, J.D., Lachman, G.B., Droege, S., Royle, J.A. \& Langtimm, C.A. (2002). Estimating site occupancy rates when detection probabilities are less than one. Ecology, 83, 2248-2255.

MacKenzie, D.I., Nichols, J.D., Royle, J.A., Pollock, K.H., Bailey, L.L. \& Hines, J.E. (2006). Occupancy estimation and modeling: inferring patterns and dynamics of species occurrence. London, U.K.: Elsevier Press.

McLoughlin, P.D., Case, R.L., Gau, R.J., Cluff, H.D., Mulders, R. \& Messier, F. (2002). Hierarchical habitat selection by barren-ground grizzly bears in the central Canadian Arctic. Oecologia, 132, 102-108.

Mitchell, M.S. \& Hebblewhite, M. (2012). Carnivore habitat ecology: integrating theory and application. In L. Boitani \& R.A. Powell (Eds), Carnivore ecology and conservation: a handbook of techniques (pp. 218255). Oxford: Oxford University Press.

Miquelle, D.G., Smirnov, E.N., Merril, T.W., Myslenkov, A.E., Quigley, H.B., Hornocker, M.G. \& Scheyer, B. (1999). Hierarchical spatial analysis of Amur tiger relationships to habitat and prey. In P.J. Seidensticker (Ed.), Riding the tiger, tiger conservation in humandominated landscapes (pp. 71-99). Cambridge: Cambridge University Press.

Mosser, A., Fryxell, J.M., Eberly, J. \& Packer, C. (2009). Serengeti real estate: density vs. fitness-based indicators of lion habitat quality. Ecology Letters, 12, 1050-1060.

Nams, V.O., Mowat, G. \& Panian, M.A. (2006). Determining the spatial scale for conservation purposes an example with grizzly bears. Biological Conservation, 128, 109-119.

Ogutu, J.O., Bhola, N. \& Reid, R. (2005). The effects of pastoralism and protection on the density and distribution of carnivores and their prey in the Mara ecosystem of Kenya. Journal of the Zoological Society of London, 265, 281-293.

Rettie, W.J. \& Messier, F. (2000). Hierarchical habitat selection by woodland caribou: its relationship to limiting factors. Ecography, 23, 466-478.

Rich, L.N., Mitchell, M.S., Gude, J.A. \& Sime, C.A. (2012). Anthropogenic mortality, intraspecific competition, and prey availability influence territory sizes of wolves in Montana. Journal of Mammalogy, 93, 722731.

Riggio, J., Jacobson, A., Dollar, L., Bauer, H., Becker, M., Dickman, A., Funston, P., Groom, R., Henschel, P., De longh, H., Lichtenfeld, L. \& Pimm, S. (2012). The size of savannah Africa: a lion's (Panthera leo) view. Biodiversity and Conservation 22, 17-35.

Ripple, W.J., Estes, J.A., Beschta, R.L. Christopher C. Wilmers, C.C., Ritchie, E.G., Hebblewhite, M., Berger, J., Elmhagen, B., Letnic, M., Nelson, M.P., Schmitz, O.J., Smith, D.W., Wallach, A.D. \& Wirsing, A.J. (2014). Status and ecological effects of the world's largest carnivores. Science, 343, 1241484.

Schuette, P., Creel, S. \& Christianson, D. (2013). Coexistence of African lions, livestock, and people in a landscape with variable human land use and seasonal movements. Biological Conservation, 157, 148-154.

Stephensen, A. (2010). Parque Nacional do Limpopo aerial wildlife census. Unpublished report for Parque Nacional do Limpopo.

Stoner, D.C., Wolfe, M.L., Rieth, W.R., Bunnell, K.D., Durham, S.L. \& Stoner, L.L. (2013). De facto refugia, ecological traps and the biogeography of anthropogenic cougar mortality in Utah. Diversity and Distributions, 1-11.

Sunarto, S., Kelly, M.J., Parakkasi, K., Klenzendorf, S., Septayuda, E. \& Kurniawan, H. (2012). Tigers need cover: Multi-scale occupancy study of the big cat in Sumatran forest and plantation landscapes. PLOS ONE, 7, e30859.

Thaker, M., Vanak, A.T., Owen, C.R., Ogden, M.B., 
Niemann, S.M. \& Slotow, R. (2011). Minimizing predation risk in a landscape of multiple predators: effects on the spatial distribution of African ungulates. Ecology, 92, 398-407.

Van Orsdol, K.G., Hanby, J.P. \& Bygott, J.D. (1985). Ecological correlates of lion social organization (Panthera leo). Journal of Zoology, 206, 97-112

Whitman, K.L. \& Packer, C. (2007). A hunter's guide to aging lions in eastern and southern Africa. Huntington Beach, CA. Long Beach Press.

Woodroffe, R. \& Ginsberg, J. (1998). Edge effects and the extinction of populations inside protected areas. Science, 280, 2126-2128.

Woodroffe, R. \& Frank, L.G. (2005). Lethal control of African lions (Panthera leo): local and regional population impacts. Animal Conservation, 8, 91-98.

Responsible Editor: M.W. Hayward 